Ta'dib: Journal of Islamic Education

Volume 21, Number 2, December 2016

\title{
Pantang Larang in The Sepinggan Village Muslim Community from The Perspective of Character Education
}

\author{
Syamsul Kurniawan \\ Faculty of Tarbiyah and Teacher Training \\ Institut Agama Islam Negeri Pontianak, Indonesia \\ E-mail: syamsulkurniawan001@gmail.com
}

\begin{tabular}{l|l|l}
\hline Received: $3^{\text {th }}$ September 2016 & Revised: $30^{\text {th }}$ September 2016 & Accepted: $12^{\text {th }}$ October 2016
\end{tabular}

\begin{abstract}
The focus of this research is on pantang larang (taboos or superstitions in Malay culture) which serves as local wisdom of the Muslim community in Sepinggan village. It is examined from the perspective of character education. As previous research indicates that the Muslim community in this area has a lot of local wisdom which includes values or a set of unwritten rules about behavior and interaction between individuals in daily life. Among them is pantang larang which contains values or moral message, especially in the context of relationship with God, with oneself and with other creatures of God, that should be manifested in thoughts, attitudes, feelings, words and deeds so as to correspond to norms, manners, and adat (customs). In other words, the Sepinggan Village Muslim community uses pantang larang as a medium as a basis for character building.
\end{abstract}

Keywords: Pantang Larang, Character Building

\begin{abstract}
Abstrak
Fokus penelitian ini adalah pantang larang (tabu atau takhayul dalam budaya Melayu) yang berfungsi sebagai kearifan lokal dari komunitas Muslim di desa Sepinggan. Hal ini diteliti dari perspektif pendidikan karakter. Seperti penelitian sebelumnya menunjukkan bahwa komunitas Muslim di daerah ini memiliki banyak kearifan lokal yang mencakup nilai-nilai atau seperangkat aturan tidak tertulis tentang perilaku dan interaksi antar individu dalam kehidupan sehari-hari. Di antaranya adalah pantang larang yang berisi nilai-nilai atau pesan moral, terutama dalam konteks hubungan dengan Tuhan, dengan diri sendiri dan dengan makhluk Allah lainnya, yang harus diwujudkan dalam pikiran, sikap, perasaan, perkataan dan perbuatan sehingga sesuai dengan norma-norma, sopan santun, dan adat (kebiasaan). Dengan kata lain, masyarakat Muslim Desa Sepinggan menggunakan pantang larang sebagai media sebagai dasar untuk membangun karakter.
\end{abstract}

Kata Kunci: Pantang Larang, Pembangunan Karakter

\section{Introduction}

Indonesians were known as people with manners, politeness, friendliness, etc. Unfortunately, all the good impression has changed now, at least in the last two decades. Moral decline, human decadence, environmental crisis are widespread and have even become the hall mark of our nation today. As a result, some of our communities find it difficult to distinguish between good and bad behavior, respectable and disgraceful, noble or shameful deeds (Harahap, 2013: 3).

Character education is urgently needed (Gumelar, 2016). The core of the formation and development orientation of the character itself is goodness, in the sense of thinking good, feeling good, and behaving good. What is means in this context is the unity of thoughts, feelings, and good deeds of a person. Bad characters such as like negligence, shamelessness and the like should be fixed (Listyati, 2012: 8). 
As followers of Islamic teachings, we are certainly aware of the importance of character. The word character in English means mental or moral qualities (Echols, 2006: 107 ), and is derived from a Greek word charassein meaning to make sharp or to deepen (Bagus, 2005: 392), whichin Islam is synonymous with the word akhlaq (morals) (read: Bakry, 1970: 17; Mukhtar, 2004: 32; Marbawi, 1350: 186). In a Hadith, it is also explained that the apostolic mission of Prophet Muhammad is toperfect morality (read: Suyuti, 1966: 92).

In addition, we should understand that the developments of the nation and character building are two different things that cannot be separated from each other. Both are like two sides of a coin. Nation building must go hand in hand with character building. Nation building will only be success if the national character building is done well.

The reasons for the widespread moral degradation, human decadence and environmental crises serve as the reason to reconsider how families and communities can contribute to the formation and development of character (Kurniawan, 2013: 19). Thus, every family or person that becomes an element of society must be involved in the creation of an atmosphere that is comfortable and conducive to the formation and development of character.

This is in line with what was once proclaimed by the Government of Indonesia in 2010 with the movement of "Cultural Education and National Character" which was asserted in the President's speech on National Education Day on May 2, 2010. Based on the President's speech, the community is expected to contributeto the formation and development of character. Local wisdom can be a positive capital in this case. Besides, political developments in Indonesia recently have provided fresh air for each region to build its own area according to the principles of autonomy, and this also means that each region should pay attention to existing local wisdom (see Mukhtar, 2007).

The Sepinggan Village Community has a lot of local wisdom which includes values or a set of unwritten rules regarding behavior and interaction in daily life. Among them is pantang larang (see Depdiknas, 2013: 1016 and 790; Sarmidi, 2015: 533). Based on the research, the Sepinggan Village Muslim community is familiar with pantang larang as values or unwritten rule that should be observedin their daily lives as ethnic Malay. It is a long timepractice and passed from one generation to the next.

Pantang larang as local widomfor Muslim community in Sepinggan Village essentially contains values or moral message, especially in the context of their relationship with God, with oneself and with other creatures of God, is seen to be embodied in the thoughts, attitudes, feelings, words and deeds, thus corresponding to the norms, manners, and adat (customs). In other words, the Sepinggan Village Muslim community uses pantang larang as a medium for the formation and development of character.

\section{Research Method}

This research is started from the research that the writerconducted throughout 2015 until mid 2016 in Sepinggan village, Semparuk Subdistrict, Sambas Regency, West 
Pantang Larang in the Sepinggan Village Muslim Community

From the Perspective of Character Education

Syamsul Kurniawan

Kalimantan Province. The focus of this research is on pantang larang which serves as local wisdom of the Muslim community in this area, and is examined from the perspective of character education.

Methodologically this research used a qualitative approach with a descriptive method. Thus, qualitatively, this researchis not based on statistical or mathematical calculation but on subjective assessment. It means that the measure of value used in this researchis not numbers or scores, but the categorization of the value or quality. This is in line with the characteristics of a descriptive method chosen for this research with a view to describe the state (the object under research) asthe way it is and in a contextual manner, as the way it occurred when the research was being conducted.

\section{Research Findings and Discussion}

1. Geographic and demographic conditions of Sepinggan Village, Sambas Regency

As prevoius desription above, the focus of this paper is onpantang larangpracticed by the Muslim community in Sepinggan village. So, before getting to the core of the discussion, first of all, I need to provide a general description of the geographic and demographic characteristics of the Sepinggan Village. This is because there is a belief that the growth and development of local wisdom is inevitabledue to the community or the environment that support it (see Asmin, 1998: 39-43).

Administratively, the village is located in Sepinggan Village,Semparuk Subdistrict, Sambas Regency, West Kalimantan. To get to this village from the city of Pontianak, we can drive and it takes approximately five to six hours. Most of the people who live in this village are ethnic Malay. In general, the climatic conditions in Sepinggan Village are not much different from other places in Sambas Regency and other areas in West Kalimantan. Sepinggan Village has a tropical climate, so that the air temperature in this area is relatively hot.

The definition of Malay in this paper refers toan ethnic group in society that still observes rituals and traditions and beliefs of the Malay (i.e. Islam) (see Hermansyah, 2015: 1). It can also be said that the Malay identity refers to people who are Muslims and practicing the traditions or adat (customs) of the Malay in everyday life. From the aspect of language, the Malay community in Sepinggan village usesthe Malay language in communicating (see Hashim, 1992: 3) particularlySambas Malay.

In terms of family relationship, ethnic Malay in the Sepinggan Villagehold to the bilateral or parental principle (see Soekamto, 1993: 56) by adopting an extended family system (see Hartini, 1992: 140). This suggests a balanced kinship system between patrilineal and matrilineal lines. Father and mother are therefore equal in the eye of achild, although the backbone of the family is still the father. This means that a father has a higher honor and is very decisive in making difficult decision in a family. In addition to the nuclear family, in one household, often there are also in-laws and brothers/sisters-in-law.

A father is the main workerand protector of the family, while a mother the person in charge of the household. Children become dependent from parents until theyare able to 
support themselves or married. The Malay community in Sepinggan village also has the terms 'close relative' and 'distant family' based on the closeness of kinship or blood relation.

In my observation, religion ispracticeden masse by the Malay people of Sepinggan Village. It can be seen from the fact that one can always find many worshipers in every mosque, especially during Friday prayer. Socialization of religious teachings have started from an early age.

Religious dakwais often carried out, especially on Islamic holy days. Each ceremony is also always conductedin an Islam way, at least with the recitation from religious leaders. Even so, the remains of animism and dynamism in the past still exist, and it appears in most forms of local wisdom, such as the rituals of tepung tawar, ngantar ajjong, bepappas, and pantang larang, or belief in mantra (see Skeat, 1967) which are originally unknown in the teachings of Islam (Yusriadi, 2006: 106).

\section{2. $\quad$ Pantang Larang as local wisdom of Muslim community in Sepinggan Village Sambas \\ Regency}

In daily life, each individual in a community is inseparable from socio-cultural influence surrounding them. Therefore, it can be understood that a person's way of thinking is affected socially and culturally. This is because the human nature creates a culture or their social environment as an adaptation to their physical, biological, and sociocultural environment.

Similarly, pantang larang serves as local wisdom developing among the Muslim community in Sepinggan village. Based on the interviews with a number of informants in the research sites, pantang larang has long become a habit andcommon practice, grew and developed, thenpassed down from one generation to the next. Thus, people who believe in pantang larang in this area almost never question the exact origin of the legacy of such wisdom. They are conditioned to accept it asthe truth about life around them, as taboos, prohibitions, and certain values are defined as local wisdom in society even if they are unwritten.

Pantang larangin the Sepinggan village Muslim community as local wisdom has been integrated as values or unwritten rules that follow their daily lives as ethnic Malay. In fact, for some writers, Malay and Islam are identical. As Hermansyah argued thatthe Malay meansthe followers of Islam. According to this view, Islam is a marker of a person's Malay identity (Hermansyah, 2015: 1).

It is true that pantang larangis not recognized in Islam. However, it is also understandable given the nature of Islam being flexible, so as to blend and merge with culture in society anywhere. Islam is a universal religion. This characteristics make it relevant to culture, time and society. The universal characteristics of Islam once again open the opportunity of developing local wisdom among followers of Islam in the archipelago (see Hermansyah, 2015: 15), included among the people of Muslim majority in Sepinggan Villagewho are Malay (Roza, 2013: 117). 
Pantang Larang in the Sepinggan Village Muslim Community From the Perspective of Character Education Syamsul Kurniawan

Obviously, not all elements of local wisdom can be consistent with the teachings of Islam. Similarly, not all of the elements of local widomcan be absorbed by the Muslim community. Generally, elements that contradictwith the teachings of Islam are removed or replaced. The arrival of Islam does not have to disconnect a society fromits past, but it should help to preserve what is good and true from the past. This awareness also causes the propagator of Islamic teachings in the past in West Kalimantan, including in Sambas, used the resources of local wisdom for Islamization (Yusriadi, 2006: 105-106). Very much in line with the principles ofal-muhafadzah 'ala al-qadm al-shalih, wa al-akhdzu bi al-jadid al-ashlah (maintaining good old traditions and obtain something new and better). In a diagram, the relationship patternbetween local wisdom and Islam is as follows:

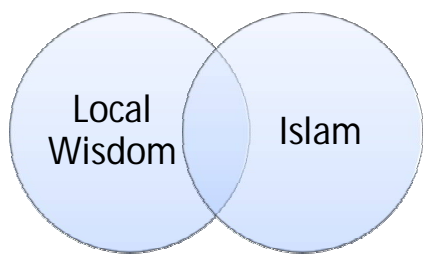

Diagram 1: The pattern of the relationship between local wisdom and Islam

The pattern of the relationship between local wisdom and Islam, as shown in Diagram 1 and the previous discussion above, appears in line with the development trend of Islam in Sambas Regency (see Yusriadi, 2006: 102), includingSepinggan village as a place where the research was conducted. In Sepinggan village, pantang larangdespitebeing authentically unknown in Islam, is maintained by the Muslim community in this area and integrated as values or unwritten rules that follow their daily lives as ethnic Malay. Obviously, pantang larangthat is not against the teachings of Islam is preserved while elementsthat arenot in line with the teachings of Islam have slowly been eroded and finally disappeared.

It should be also understood that pantang larang developing in this area is growing in a mythical condition among the people.Oral remarks from generation to generationare often heard from parents, such as grandfather (nek aki), or grandmother (nek uwan). When carefully examined, the taboos or restrictions passed down fromolder generation contain wisdom and values.Obviously, the remarks in the form of words or sentences containing taboos or restrictions could allegedly stems from a number of cases resolved because it can be rationalized that its existence is taken for granted, passed down between generations in some situations without clear reasons.

Based on the results of observation, the Muslim community in Sepinggan village has used this pantang larang as a mediumfor building character among them. Moreover, pantang larang embraces a set of values or rules not properly written in order to relate with God, with ourselves, with others and with nature or the environment that should be embodied in the thoughts, attitudes, feelings, words and deeds, thus corresponding to 
norms, manners, and adat (customs). If drawn into a diagram, then pantang larang in the village following Sepinggan can be described as follows:

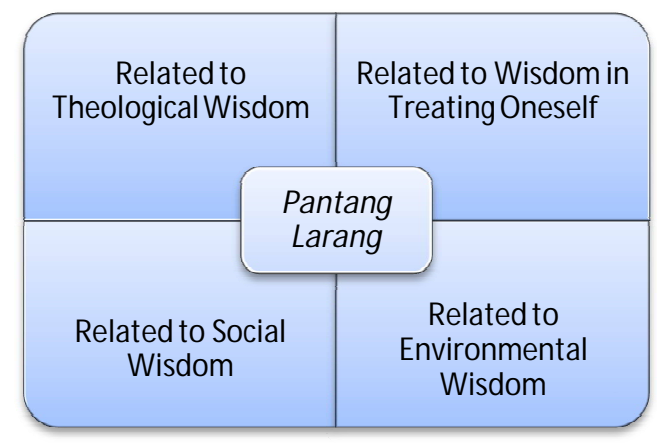

\section{Diagram 2: Classification of pantang larang in Sepinggan Village}

Based on interviews heldat the research sites with a number of informants, the following information about pantang larangis found among the people:

a. Pantang larang related to theological wisdom

\begin{tabular}{|l|l|l|l|}
\hline No & Pantang larang & Consequences of violation & Rationale \\
\hline 1 & Step over the Qur'an & Tullah (receiving misfortune). & $\begin{array}{l}\text { Al-Quran is the holy } \\
\text { book, not appropriate to } \\
\text { step over. }\end{array}$ \\
\hline 2 & $\begin{array}{l}\text { Playing outside ahead of } \\
\text { sunset prayer time for } \\
\text { children. }\end{array}$ & Abducted by ghosts & $\begin{array}{l}\text { It is time to prepare } \\
\text { forsunset prayer. }\end{array}$ \\
\hline 3 & $\begin{array}{l}\text { Eating sugar cane ahead of } \\
\text { sunset prayer time for } \\
\text { children. }\end{array}$ & $\begin{array}{l}\text { the mother or the father of the child } \\
\text { will die }\end{array}$ & $\begin{array}{l}\text { It is time to prepare for } \\
\text { sunset prayer. }\end{array}$ \\
\hline
\end{tabular}

b. Pantang larang related to wisdom in treating one self

\begin{tabular}{|l|l|l|l|}
\hline No & Pantang larang & Consequences of violation & Rationale \\
\hline 1 & Sitting on a pillow & Pain in the behind & $\begin{array}{l}\text { It is unethicalto sit on a } \\
\text { pillow because it is used } \\
\text { for laying your head on. }\end{array}$ \\
\hline 2 & $\begin{array}{l}\text { Lifting legs while lying } \\
\text { down on your stomach }\end{array}$ & the mother or the father will die & $\begin{array}{l}\text { Sleep on your stomach } \\
\text { with feet up is not good } \\
\text { for your health;may result } \\
\text { in abnormalities of the } \\
\text { lungs; It also teaches } \\
\text { someone about manners. }\end{array}$ \\
\hline 3 & Leaving the fooduneaten & The chickens raised will die & $\begin{array}{l}\text { Leaving food uneatenis } \\
\text { wasteful. }\end{array}$ \\
\hline 4 & Cutting nails at night & short life & $\begin{array}{l}\text { It is feared that one may } \\
\text { cut their finger instead of } \\
\text { their nails. }\end{array}$ \\
\hline 5 & $\begin{array}{l}\text { Sewing clothes while being } \\
\text { worn }\end{array}$ & Bad luck & $\begin{array}{l}\text { One can be injured by the } \\
\text { needle }\end{array}$ \\
\hline
\end{tabular}


Pantang Larang in the Sepinggan Village Muslim Community

From the Perspective of Character Education

Syamsul Kurniawan

\begin{tabular}{|c|c|c|c|}
\hline 6 & $\begin{array}{l}\text { Sitting in the front door for } \\
\text { girls }\end{array}$ & Becoming a spinster & It is impolite. \\
\hline 7 & Sleeping after meal & Bloated stomach or obesity. & $\begin{array}{l}\text { Sleeping after meal is not } \\
\text { good for health. }\end{array}$ \\
\hline 8 & $\begin{array}{l}\text { Pullingout eyelashes and } \\
\text { shaving eyebrows }\end{array}$ & Seeing ghosts & $\begin{array}{l}\text { Some ulemas prohibit } \\
\text { these activities. }\end{array}$ \\
\hline 9 & $\begin{array}{l}\text { Pregnant women walking } \\
\text { under a clothesline }\end{array}$ & Difficult childbirth & $\begin{array}{l}\text { It is feared that a pregnant } \\
\text { woman may fall over or } \\
\text { het caught by clothesline } \\
\text { thereby harming the } \\
\text { womb }\end{array}$ \\
\hline 10 & $\begin{array}{l}\text { Pregnant women sleeping } \\
\text { late }\end{array}$ & Her face will be swollen & $\begin{array}{l}\text { Ethically, getting up late } \\
\text { is impolite. }\end{array}$ \\
\hline 11 & $\begin{array}{l}\text { Pregnant women looking at } \\
\text { solar eclipse }\end{array}$ & $\begin{array}{l}\text { Iddab (deformity) in children, such } \\
\text { as facial mole. }\end{array}$ & $\begin{array}{l}\text { Looking at solar eclipse } \\
\text { directly may cause } \\
\text { blindness. }\end{array}$ \\
\hline 12 & $\begin{array}{l}\text { Pregnant women wrapping } \\
\text { a towel around neck }\end{array}$ & $\begin{array}{l}\text { Umbilical cord wrapped around the } \\
\text { baby's neck at the time of birth }\end{array}$ & Ethically, it isimpolite. \\
\hline 13 & Eating twin bananas & Having twin children & $\begin{array}{l}\text { Importance to stay away } \\
\text { from gluttony. }\end{array}$ \\
\hline 14 & $\begin{array}{l}\text { Eating directlyfrom pot } \\
\text { (rice bowls) }\end{array}$ & $\begin{array}{l}\text { Iddab (deformity) in children, or } \\
\text { ugly face }\end{array}$ & $\begin{array}{l}\text { It is impolite, because } \\
\text { eating should use a plate } \\
\text { or bowl. }\end{array}$ \\
\hline 15 & Eating in squatting position & Difficult to get livelihood & $\begin{array}{l}\text { It is impolite as normally } \\
\text { people defecate or urinate } \\
\text { in a squatting position. }\end{array}$ \\
\hline 16 & Eating in the dark & Inviting ghosts & $\begin{array}{l}\text { It is feared that food will } \\
\text { be spilled. fish bones may } \\
\text { get stuck in your throat. }\end{array}$ \\
\hline 17 & $\begin{array}{l}\text { Going out during sun } \\
\text { shower (one can be exposed } \\
\text { to sun showerbybesunting } \\
\text { (tucking the grass next to } \\
\text { the ear). }\end{array}$ & $\begin{array}{l}\text { Experiencing a high fever caused } \\
\text { by jaringghost. }\end{array}$ & $\begin{array}{l}\text { Sunshower can be bad for } \\
\text { health. }\end{array}$ \\
\hline 18 & $\begin{array}{l}\text { Using umbrellas in the } \\
\text { house }\end{array}$ & short-lived & $\begin{array}{l}\text { It is inappropriate. In } \\
\text { addition, local people } \\
\text { analogize with "covering } \\
\text { a dead bodywith an } \\
\text { umbrella from the house } \\
\text { to the cemetery". }\end{array}$ \\
\hline 19 & Eating shrimp head & Becoming stupid & $\begin{array}{l}\text { The termotak } \\
\text { udang(shrimp brain) } \\
\text { refers to a foolish person. } \\
\text { In addition, the head of } \\
\text { the shrimp is not really } \\
\text { good for health. }\end{array}$ \\
\hline 20 & Sleeping late & $\begin{array}{l}\text { Chickens have picked all the } \\
\text { worms }\end{array}$ & $\begin{array}{l}\text { Getting up late } \\
\text { isinappropriate as it is } \\
\text { synonymous with } \\
\text { laziness. }\end{array}$ \\
\hline
\end{tabular}


c. Pantang larang related to social wisdom

\begin{tabular}{|c|c|c|c|}
\hline No & Pantang Larang & Consequences of violation & Rationale \\
\hline 1 & $\begin{array}{l}\text { Baby's clothes soaked in } \\
\text { the water for a long time. }\end{array}$ & The baby may havestomach pain. & $\begin{array}{l}\text { It is feared that the clothes } \\
\text { will produce bad smell if } \\
\text { not immediately washed. }\end{array}$ \\
\hline 2 & $\begin{array}{l}\text { Carryinga baby on the } \\
\text { back }\end{array}$ & Tullah (misfortune) & $\begin{array}{l}\text { It is feared that the baby } \\
\text { will fall }\end{array}$ \\
\hline 3 & Whistling in the house & Inviting ghosts & $\begin{array}{l}\text { Ensuring a pleasant } \\
\text { atmosphere at home }\end{array}$ \\
\hline 4 & $\begin{array}{l}\text { Spitting at the time of } \\
\text { defecation }\end{array}$ & Dental damage & $\begin{array}{l}\text { Maintaining the } \\
\text { cleanliness of the } \\
\text { restroom. }\end{array}$ \\
\hline 5 & $\begin{array}{l}\text { Taking back goods that } \\
\text { have been given to } \\
\text { someone else }\end{array}$ & $\begin{array}{l}\text { Buruk siku (ugly elbow) The elbow } \\
\text { will suffer from skin diseases such } \\
\text { as ringworm. }\end{array}$ & $\begin{array}{l}\text { Taking back the goods } \\
\text { that have been given to } \\
\text { others showsinsincerity. }\end{array}$ \\
\hline 6 & Pointingat the rainbow & Jari kudung (disfigured finger). & $\begin{array}{l}\text { It is feared that one may } \\
\text { accidently point at } \\
\text { someone else, thus } \\
\text { potentially leading to } \\
\text { misunderstanding. }\end{array}$ \\
\hline 7 & $\begin{array}{l}\text { Girls singing in the kitchen } \\
\text { while cooking }\end{array}$ & Be married to an old man & $\begin{array}{l}\text { It is feared that the dishes } \\
\text { will be contaminated with } \\
\text { saliva for fun singing. }\end{array}$ \\
\hline 8 & $\begin{array}{l}\text { Sweeping the floor of the } \\
\text { house at night }\end{array}$ & Shortage of sustenance & Not good for health. \\
\hline 9 & Let the rice jar empty. & Shortage of sustenance & $\begin{array}{l}\text { It is feared that when } \\
\text { guests come there is no } \\
\text { food supply at all to serve } \\
\text { them. }\end{array}$ \\
\hline 10 & $\begin{array}{l}\text { Pregnant women berating } \\
\text { or revealing someone's } \\
\text { weaknesses }\end{array}$ & $I d d a b$ (deformity) in children & $\begin{array}{l}\text { Not to hurt someone's } \\
\text { feelings }\end{array}$ \\
\hline 11 & $\begin{array}{l}\text { Disobeying or yelling at } \\
\text { parents or in-laws. }\end{array}$ & Tullah (misfortune) & $\begin{array}{l}\text { Disobeying or yelling at } \\
\text { parents or in-laws is not } \\
\text { justified in view of the } \\
\text { religious and social norms. }\end{array}$ \\
\hline
\end{tabular}

d. Pantang larang related to environmental wisdom

\begin{tabular}{|l|l|l|l|}
\hline No & Pantang larang & Consequences of violation & Rationale \\
\hline 1 & $\begin{array}{l}\text { Frolicking in the } \\
\text { forest }\end{array}$ & inviting ghost & $\begin{array}{l}\text { The forest is not a } \\
\text { place to frolic }\end{array}$ \\
\hline 2 & $\begin{array}{l}\text { Reprimanding } \\
\text { something strange in } \\
\text { the woods }\end{array}$ & Being possessed & $\begin{array}{l}\text { Avoidingunseen } \\
\text { beings. }\end{array}$ \\
\hline 3 & $\begin{array}{l}\text { Whistling in the } \\
\text { woods }\end{array}$ & inviting ghost & $\begin{array}{l}\text { Avoiding unseen } \\
\text { beings or animals. }\end{array}$ \\
\hline 4 & $\begin{array}{l}\text { Taking 'odd' things } \\
\text { found in the woods }\end{array}$ & Being followed by ghost & $\begin{array}{l}\text { Avoiding unseen } \\
\text { beings }\end{array}$ \\
\hline 5 & $\begin{array}{l}\text { Carelessly urinating } \\
\text { in the woods }\end{array}$ & $\begin{array}{l}\text { Burrut, which is swelling of } \\
\text { the testicles. }\end{array}$ & $\begin{array}{l}\text { Environmental } \\
\text { wisdom. }\end{array}$ \\
\hline
\end{tabular}


Pantang Larang in the Sepinggan Village Muslim Community From the Perspective of Character Education Syamsul Kurniawan

\begin{tabular}{|l|l|l|l|}
\hline 6 & $\begin{array}{l}\text { Roastingbelacan } \\
\text { (shrimp paste) in the } \\
\text { woods }\end{array}$ & inviting ghost & $\begin{array}{l}\text { environmental } \\
\text { wisdom }\end{array}$ \\
\hline 7 & Urinating on graves & $\begin{array}{l}\text { Burrut, which is swelling of } \\
\text { the testicles. }\end{array}$ & $\begin{array}{l}\text { Environmental } \\
\text { wisdom. }\end{array}$ \\
\hline 8 & $\begin{array}{l}\text { Torture, hitting or } \\
\text { hurting the animal for } \\
\text { pregnant women }\end{array}$ & $\begin{array}{l}\text { Children will be born with } \\
\text { disability or deformity } \\
\text { (iddab). }\end{array}$ & $\begin{array}{l}\text { Importance of loving } \\
\text { animals. }\end{array}$ \\
\hline 9 & $\begin{array}{l}\text { Mocking or laughing } \\
\text { at apes or monkeys. }\end{array}$ & $\begin{array}{l}\text { Children will be born with } \\
\text { disability or deformity } \\
\text { (iddab), e.g. having a } \\
\text { monkey's face }\end{array}$ & $\begin{array}{l}\text { Importance of proper } \\
\text { treatment of animals. }\end{array}$ \\
\hline 10 & $\begin{array}{l}\text { Burying a cat after } \\
\text { being hit in an } \\
\text { accident }\end{array}$ & $\begin{array}{l}\text { Getting a misfortune or } \\
\text { calamity }\end{array}$ & $\begin{array}{l}\text { Importance of proper } \\
\text { treatment of animals. }\end{array}$ \\
\hline
\end{tabular}

Source: Adapted from a number of informantsduring research

The pantang larangdescribed above are still observed by the Muslim community in Sepinggan village. In addition tothe abovepantang larang, there are also taboos that are difficult to find the rationale such as a prohibition on taking pictures in an odd number, as people believe that it would lead to the death of one of people in the photograph. Another pantang laranghitting the water surface when boating on the river if you do not want to get struck by crocodiles. And so is the case with many other taboos.

\section{Pantang larangas Local Wisdom in Character Building}

The Sepinggan village Muslim community is rich with local wisdom, one of which is pantang larang. In fact, pantang larang seems to restrict individual freedom since it makes no sense at times. The Pantang larang that is still practiced majority Muslim community in Sepinggan village serves as a survival guide that includes what to do and what not to. Moreover, it has become commonplace that traditional society learn through oral tradition. Pantang larangan oral practice growing through oral tradition from one generation to the next.

In Sepinggan village, the Muslim community,in fact,has many kinds of pantang larang. Some of which have been reviewed above. Not all of the pantang larangmake no sense. This is in line with the findings at the research sites where there areseveral taboosthat are difficult to find the rationale, such as a ban on taking a picture of an odd number people, of which people believe wouldcause one of themto die. However, the majority of pantang larangmake sense and and are relevant to values of character building.

Pantang larang thrive in the midst of society, especially with ragard to social environment, culture, and nature of the place they reside in. More importantly, that sort of knowledge serves as part of their local wisdom. Previous generations use oral tradition to introduce and pass on local wisdomasheritage. So,pantang larang, implies a profound message, especially regarding the importance of building good relationship with others and the nature, and to develop ethics or manners in everyday life. 
The interviews with a number of informants at the research site indicatethat pantang larang in the past was used as a strategy, especially for parents to teach their children about how to interact with others and the nature, including supernatural beings that even though they are unseen, they live side by side with humans. In terms of health,pantang larang teaches the community to live a healthy life, and in addition it can be connected with religious teachings.

Pantang larangalso deals with ethical lessons as described above. For example, a girl is prohibited to sit on the doorway. This prohibition teachespeople not tositin the way as it is impolite and may disturb those who need pass by. Similarly, one is notallowed tosleep late as for most people such habit is synonymous with laziness. It is obviously also related to improving social relations (morality) prevailing in society.

Pantang larang also can be seen as an effort to maintain the health and hygiene. For example, the ban on sleeping on one's stomach, cutting the nails at night, etc. All is a manifestation of the wisdom of parents to teach life lessons to their children.

Meanwhile there are also prohibitions related to the environmental health. For example, there is apantang larang which bans children to go out during a sun shower which is not good for their health, because the mix of heat and rain water might cause fever. However, there is an important moral message in suchpantang larang, that is do not let your child play in a weather condition that is unhealthy and unsafe.

The ban on leaving food uneaten is also very close to the teachings of religion, especially Islam which prohibits wasteful habit. Moreover, it also teaches the children to appreciate food, regardless of the amount. Such attitude should in fact be taughtfrom an early age because it will shape one's behavior whenthey reach maturity

A child is not allowed to play outside the house ahead ofsunset prayer time suggests that it is important for children to join the prayer. One is not allowed to urinateand roast shrimp paste in the woods teaches about the importance of 'being kind' to the environment, including not to contaminate it as a form of environmental wisdom.In addition roasting something in the woods may also cause fire. Positive environmental attitudeneeds to be cultivated in a person's character. This is completely understandableas disasters such as haze, floods, landslides, etc., are partly due to the destructive actions of man on nature (Kurniawan, 2006).

In this context, pantang larangsuggests that the environment needs to be preserved. This is in line with the results of the interviewswith a number of informants at the research site, where most people recognize the importance of forests and sustainability need to be maintained, because for them the forest is a natural resource that providesfor their livelihood.

Thus, the Muslim community in Sepinggan village has usedsuch bansas the media forcharacter building. Pantang larang embraces a set of values or unwritten rules in order to relate with God, with oneself, with others and with nature or the environment, and 
Pantang Larang in the Sepinggan Village Muslim Community

From the Perspective of Character Education

Syamsul Kurniawan

should be manifested in thoughts, attitudes, feelings, words and deeds, in order to correspond to the existing norms, manners, and adat (customs).

\section{Conclusion}

It can be concluded that the Muslim community in Sepinggan villagerecognize the values of pantang larangas a set of unwritten rules about behavior and social interaction in everyday life. As local wisdom, pantang larang has been used since long a go as a medium for the formation and development of character in this village.

Pantang larang is a set of dos and don'ts that may result in either real or superstitious consequences. Pantang larangserves asmoral values or message, especially in order to establish a good relationship with God, oneself, and fellow creatures of God that should be embodied in the thoughts, attitudes, feelings, words and deeds, so as to correspond to the existing norms, manners, and adat (customs).

From theperspective of character education, obviously pantang larangis still relevant to the effort in establishingvalues related to character building, especially in communities that are still relatively traditional and still acknowledge the existence of local wisdom. It can also be concluded that through pantang larang, the community has its share in the formation and development of noble character. 


\section{References}

Amin, Ahmad. (1977). Etika (Ilmu Akhlaq). Jakarta: Bulan Bintang.

Antara Sulteng, "Linda: Pendidikan Karakter Bangsa Mendesak", dalam sulteng.antaranews.com/berita/3299/linda-pendidikan-karakter-bangsa-mendesak (akses 4 Juli 2016).

Bagus, Lorens. (2005). Kamus Filsafat. Jakarta: Gramedia.

Bakry, Hasbullah. (1970). Sistematika Filsafat. Jakarta: Wijaya.

Bothoul, Gasthoul. (1998). Teori-teori Filsafat Sosial Ibn Khaldun, terj. Yudian W. Asmin. Jakarta: Titian Ilahi Press.

Depdiknas. (2013). Kamus Besar Bahasa Indonesia. Jakarta: Gramedia.

Echols, John M. dan Hassan Shadily. (2006). Kamus Inggris-Indonesia. Jakarta: Gramedia.

Harahap, Syahrin. (2013). "Restorasi Karakter Bangsa di Arus Global", disampaikan dalam Orasi Ilmiah di IAIN Pontianak.

Hartini, dan Kartasapoetra. (1992). Kamus Sosiologi dan Kependudukan. Jakarta: Bumi Aksara.

Hashim, Muhammad Yusoff. (1992). Pensejarahan Melayu: Kajian tentang Tradisi Sejarah Melayu Nusantara. Kuala Lumpur: Dewan Bahasa dan Pustaka.

Hermansyah. (2015). Islam dan Melayu di Borneo. Pontianak: IAIN Pontianak Press.

Kurniawan, Syamsul. (2006). "Tanah Airku Murka", dalam Pontianak Post, 29 Nopember.

Kurniawan, Syamul. (2013). Pendidikan Karakter. Yogyakarta: Arruzz Media.

Listyati, Retno. (2012). Pendidikan Karakter. Jakarta: Erlangga.

Marbawi, Idris. (1350). Kamus Marbawi. Mesir: al-Bab al-Halabi.

Mukhtar, Abdul Choliq. (2004). Hadits Nabi dalam Teori dan Praktek. Yogyakarta: TH Press.

Mukhtar, Andi M. dan Syarifuddin. (2007). Mengungkap Kearifan Lingkungan Sulawesi Selatan. PPLH Regional Sulawesi, Maluku, Papua, Kementerian Lingkungan Hidup RI dan Masagena Press Makassar.

Roza, Ellya. (2013). Islam dan Tamadun Melayu. Pekanbaru, Riau: Daulat Riau.

Sarmidi, Gatot. "Keberadaan Wacana Pantang Larang Berlaras Gender Sebagai Tradisi Lisan, Fenomena Bahasa, dan Sastra Lisan Indonesia", dalam Jurnal Inspirasi Universitas Kanjuruhan Malang, Vol.5, Nomor 1 tahun 2015, h. 553.

Skeat, Walter William. (1967). Malay Magic. Newyork: Dover Publications, Inc..

Soekamto, Soerjono. (1993). Kamus Sosiologi. Jakarta: Rajawali Press.

Suyuti, Jalaluddin. (1966). al-Jami’ al-Shaghir. Mesir: Dar al-Qalam.

Yusriadi, dan Patmawati (ed.). (2006). Dakwah Islam di Kalimantan Barat. Pontianak: STAIN Pontianak Press. 